DOI: $10.31249 / \mathrm{rsm} / 2018.03 .05$

\title{
E.A. Крылова
}

\section{РОССИЯ В ПРОГРАММАХ ПАРААМЕНТСКИХ ПАРТИЙ ФРГ в 2017 r.}

Аннотация. В статье речь идет о том, какими видят взаимоотношения с Россией германские партии, прошедшие в Парламент ФРГ по итогам выборов 24 сентября 2017 г. На основе анализа программ этих партий делается вывод, что несмотря на все сложности, Россия по-прежнему остается одним из важнейших внешнеполитических партнеров Германии.

Ключевые слова: Российско-германские отночения, Парламент ФРГ, выборы в Германии, Бундестаг.

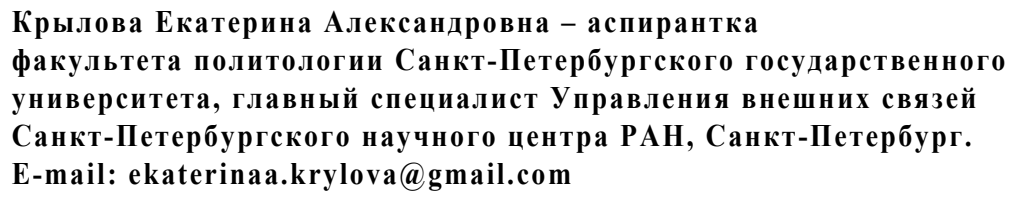

E.A. Krylova. Russia in the Programs of the Parliamentary Parties of Germany in 2017

Abstract. The article describes the views of the German parliamentary parties after elections in September 24, 2017 on the relationship with Russia. Analysing the programs of these parties, the author concludes that despite all difficulties and problems, Russia is still one of the most important foreign policy partners for Germany.

Keywords: Russian-German relations, German Parliament, elections in Germany, Bundestag.

Krylova Ekaterina Alexandrovna - Postgraduate student

of the Faculty of Political Science St. Petersburg State University,

Headspecialist of the Foreign Relations Department

of the Saint-Petersburg Scientific Centre RAS.

E-mail: ekaterinaa.krylova@gmail.com 
Федеративная Республика Германия, продолжая оставаться локомотивом европейской экономики, выступает неформальным лидером в политической жизни Европы. Этот факт вызывает повышенный интерес к любым изменениям, происходящим в стране. Последние выборы в Бундестаг показали, что политическая карта Германии претерпела существенные изменения.

Выборы в Бундестаг в 2017 г. стали уникальными. С 24 сентября в парламенте работают семь партий [1]. Пятипроцентный барьер преодолели как Христианско-демократический союз Германии (ХДС) с Христианскосоциальным союзом (ХCC), получившие 246 мест в Парламенте, так и Социалдемократическая партия Германии (СДПГ, 153 места), партия «Альтернатива для Германии» (АДГ, 92 места), «Свободная демократическая партия Германии» (СвДП, 80 мест), партия «Левые» (69 мест), «Зеленые» (67 мест). Количество депутатов возросло пропорционально увеличившейся явке избирателей [4]. Впервые в истории партии не смогли на протяжении почти пяти месяцев сформировать коалицию и новое правительство.

Разные партии по-разному представляют себе варианты взаимодействия с Россией.

Партия ХДС традиционно поддерживается крупным бизнесом Германии. Этот бизнес заинтересован в экономическом сотрудничестве с Россией. Соответственно, и партия не против российско-германского сотрудничества (в программе ХДС Россия упомянута трижды), но тем не менее в приоритетах у ХДС остается работа с США и НАТО.

ХДС заинтересована в разрешении конфликта между РФ, Украиной и ЕС в целях реализации проекта объединенной Европы. ХДС поддерживает предложение создать союз безопасности в Европе, несмотря на убежденность в принадлежности ФРГ блоку НАТО [8]. ХДС призывает Россию осуществлять Минские соглашения. Россия также упомянута в контексте возвращения немцев на историческую родину. Идеологически ХДС не поддерживает политику Москвы по проблеме прав человека, работы некоммерческих организаций. Однако экономическое крыло ХДС лоббирует инвестиционную политику в РФ, поддержку бизнеса на территории РФ. С 2013 г. ХДС стала резче критиковать действия РФ на постсоветском пространстве. Катализатором стал вопрос Украины и Крыма, расхождения во взглядах на геополитическое сотрудничество ЕС и РФ на просторах СНГ и Балканах [там же].

Социал-демократы, движущиеся в фарватере политики бывшего канцлера Шрёдера, имеют много общего с ХДС во взглядах на Россию, поскольку тоже представляют интересы крупных немецких фирм и предприятий. Однако политика СДПГ в отношении России остается более либеральной, и ей на страницах предвыборной программы было уделено внимание 6 раз. Подтверждением важности для этой партии российской темы стали выступления партийных лидеров относительно упрощения визового сотрудничества, внут- 
реннего развития России. Однако украинский кризис сблизил СДПГ и ХДС в области санкционной политики. Условием снятия санкций, как говорится в программе СДПГ, является претворение в жизнь Минских соглашений.

В предвыборной программе СДПГ 2017 г. речь идет о совместной с Россией ответственности за свободу и мир, борьбу с терроризмом, о необходимости диалога между правительствами и народом, а также о том, что открытая Россия обеспечит свободу и стабильность на континенте. Россия, по мнению СДПГ, является неотъемлемой частью Европы, а свобода и безопасность в Европе возможна только с Россией, а не без нее. Российская Федерация упоминается и тогда, когда речь идет о многостороннем сотрудничестве по линии ОБСЕ, ООН, Совета Европы. Однако отношения с Россией названы одним из вызовов для трансатлантического партнерства [9].

«Альтернатива для Германии» выступает за учет интересов России на восточном направлении ЕС, совместное разрешение проблем, включая украинский вопрос и отмену санкций [7]. Партия позиционирует себя как выразительница настроений российских немцев, консервативных слоев немецкого общества, интеллигенции Германии. Среди ее предвыборных ходов - перевод партийной программы на русский язык, в самой программе отношения с Россией описываются дважды. Разрядка отношений с Россией, по мнению АДГ, это предпосылка для установления долгосрочного сотрудничества в Европе [там же]. Кроме того, предполагается включить Россию в совместную структуру безопасности.

У Свободной демократической партии Германии прагматическая повестка; в этой программе Россия была упомянута 10 раз. В основном партия представляет мелкий и средний бизнес, поэтому у либералов заинтересованность в работе с РФ минимальна. России отведен отдельный параграф под заголовком «Четкие действия в отношении России», в котором делается акцент на необходимость диалога с Россией как с соседом на европейском континенте, на урегулирование ситуации вокруг Украины. Демократы призывают обратить особое внимание на соблюдение прав человека в России. В параграфе «Отношения с НАТО» СвДП, подчеркивая роль блока как гаранта безопасности, также упоминает о важности диалога с Россией [3].

Германские «Левые» настроены на деэскалацию в отношениях и с Россией, и на всем восточном направлении политики ФРГ. На страницах программы Россия была упомянута 11 раз [6]. «Левые» - это одна из партий, выражающих антимилитаристские взгляды; партия выступает за усиление роли $\mathrm{OOH}$ в урегулировании мировых конфликтов, за развитие интеграционных процессов в ЕС. Ее члены говорят об отмене санкций в отношении Москвы, окончании политики изоляции Российской Федерации и расширении сотрудничества EC с Россией. На страницах предвыборной программы упоминается о присутствии России в Сирии, об укреплении позиций ОБСЕ в Европе, прекраще- 
нии присоединения новых членов к договору НАТО и о строительстве безопасности Европы совместно с Россией, а не против нее. В программе также говорится о том, что базирующиеся вдоль границ России системы противоракетной обороны (ПРО) ЕС и НАТО создают угрозу миру в Европе [6].

«Зеленые» и «Союз 90» позиционируют себя как бескомпромиссные критики политики России по вопросам нарушения прав человека, политики Российской Федерации на Балканах, на постсоветском пространстве и в Сирии. Россия в предвыборной программе «Зеленых» была упомянута трижды [2]. Говоря о политике расширения ЕС и сотрудничестве с соседями на востоке, партия предлагает либерализировать визовый режим, в том числе и для России, в целях интенсификации обмена в области образования, спорта, культуры. «Либерализация европейско-германской визовой политики является важнейшим ключом к реформам и социальным изменениям за пределами Европейского союза», - указывается в программе. В ней также идет речь о необходимости предотвращения конфликта «Запад - Восток» и реформировании структуры НАТО.

Таким образом, в программах всех парламентских партий уделено немало места взаимоотношениям с Россией. Как показали федеральные выборы, карта электоральных предпочтений в Германии сильно изменилась в сторону правого консерватизма. Большая часть избирателей, ушедших от центристских партий к АДГ и «Левым», готова пересматривать внутреннюю и внешнюю политику. Но несмотря на это, существенных количественных и качественных изменений в российско-германских отношениях не ожидается.

Продолжавшиеся с конца ноября 2017 г. переговоры о создании коалиционного правительства между ХДС / ХСС и социал-демократами подошли к завершению 7 февраля 2018 г. Результатом стало подписание коалиционного договора под названием «Новое начало для Европы. Новая динамика для Германии. Новая солидарность для нашей страны» [5]. Россия как крупнейший европейский сосед была упомянута в основополагающем документе 10 раз. В документе говорится о ее возрастающей роли в мире, о необходимости возобновления работы совета Россия - НАТО, а также совместной работы ФРГ и России в области безопасности и свободы. России отводится важная роль в процессе урегулирования важных международных проблем, обеспечения гарантий суверенитета стран, основанного на принципах работы ОБСЕ. О России упоминается в связи с сотрудничеством между гражданским обществом и бизнесом, крымским кризисом, ситуацией на восточной Украине и соблюдением Минских договоренностей.

Цель политики в отношении России, как следует из Договора, - это возвращение к отношениям, основанным на взаимном доверии и балансе интересов, которые снова позволят наладить тесное партнерство между странами. 


\section{РОССИЯ И МИР В ХХІ ВЕКЕ}

Германия стремится увеличить сотрудничество с гражданским обществом, в том числе укрепляя работу «Петербургского диалога».

Таким образом, при всех геополитических разногласиях Россия остается важным направлением внешней политики ФРГ. Несмотря на кризис в отношениях ЕС с Российской Федерацией, торговые и экономические двусторонние отношения продолжают развиваться.

\section{Библиография}

1. Bundestagswahl 2017: Ergebnis, Sitzverteilung, Koalitionen, Kosten. 25.09.2017 // Wahlen in Deutschland [Электронный ресурc]. URL: https://bundestagswahl-2017.com/ergebnis/ (Дата обращения: 25.09.2017.)

2. Bundestagswahlprogramm 2013 von Bündnis 90 / DIE GRÜNEN. Zeit für den grünen Wandel. 25.09.2017 // DIE GRÜNEN: Official Website [Электронный pecypc]. URL: http://www. gruene.de/partei/gruenes-wahlprogramm-2013.html (Дата обращения: 25.09.2017.)

3. Das Programm der Freien Demokraten zur Bundestagswahl 2017: «Schauen wir nicht länger zu» 2017 // Free Demokraten (FDP): Official Website [Электронный pecypc]. URL: https:// www.fdp.de/sites/default/files/uploads/2017/08/07/20170807-wahlprogramm-wp-2017-v16.pdf (Дата обращения: 25.09.2017.)

4. Endgültige Ergebnisse. Bundestagswahl 2017 // Der Bundeswahlleiter: Official Website [Электронный ресурc]. URL: https://www.bundeswahlleiter.de/bundestagswahlen/2017/ergebnisse. html (Дата обращения: 07.10.2017.)

5. Koalitionsvertrag zwischen CDU, CSU und SPD. Ein neuer Aufbruch für Europa. Eine neue Dynamik für Deutschland. Ein neuer Zusammenhalt für unser Land 2018 // Sozialdemokratische Partei Deutschlands (SPD): Official Website [Электронный ресурc]. URL: https://www.spd.de/ fileadmin/Dokumente/Koalitionsvertrag/Koalitionsvertrag_2018.pdf (Дата обращения:17.02.2018.)

6. Langfassung des Wahlprogramms zur Bundestagswahl 2017. Sozal gerecht. Frieden. Für alle. Die Zukunft, für die wir kämpfen! 2017 // DIE LINKE: Official Website [Электронный pecypc]. URL: https://www.die-linke.de/fileadmin/download/wahlen2017/wahlprogramm2017/die_ linke_wahlprogramm_2017.pdf (Дата обращения: 25.09.2017.)

7. Programm für Deutschland. Wahlprogramm der Alternative für Deutschland für die Wahl zum Deutschen Bundestag am 24 September 2017 // Alternative für Deutschland (AfD): Official Website [Электронный ресурc]. URL: https://www.afd.de/wp-content/uploads/sites/111/2017/06/ 2017-06-01_AfD-Bundestagswahlprogramm_Onlinefassung.pdf (Дата обращения: 25.09.2017.)

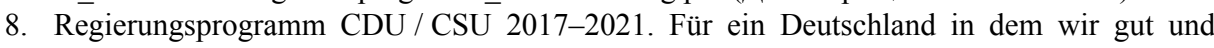
gerne leben 2017 // Christlich-Demokratische Union Deutschlands (CDU): Official Website [Электронный pecypc]. URL: https://www.cdu.de/system/tdf/media/dokumente/170703 regierungsprogramm2017.pdf (Дата обращения: 25.09.2017.)

9. Unser Regierungsprogramm für Deutschland. Zeit für mehr Gerechtigkeit 2017 // Sozialdemokratische Partei Deutschlands (SPD): Official Website [Электронный ресурc]. URL: https:// www.spd.de/fileadmin/Dokumente/Bundesparteitag_2017/Es_ist_Zeit_fuer_mehr_Gerechtigkeit-Unser_ Regierungsprogramm.pdf (Дата обращения: 24.09.2017.) 


\section{References}

Bundestagswahl 2017: Ergebnis, Sitzverteilung, Koalitionen, Kosten. 25.09.2017 // Wahlen in Deutschland [Электронный pecypc]. URL: https://bundestagswahl-2017.com/ergebnis/ (Data obrashhenija: 25.09.2017.)

Bundestagswahlprogramm 2013 von Bündnis 90 / DIE GRÜNEN. Zeit für den grünen Wandel. 25.09.2017 // DIE GRÜNEN: Official Website [Электронный pecypc]. URL: http://www. gruene.de/partei/gruenes-wahlprogramm-2013.html (Data obrashhenija: 25.09.2017.)

Das Programm der Freien Demokraten zur Bundestagswahl 2017: «Schauen wir nicht länger zu» 2017 // Free Demokraten (FDP): Official Website [Электронный ресурc]. URL: https://www.fdp.de/sites/default/files/uploads/2017/08/07/20170807-wahlprogramm-wp-2017-v16.pdf (Data obrashhenija: 25.09.2017.)

Endgültige Ergebnisse. Bundestagswahl 2017 // Der Bundeswahlleiter: Official Website [Электронный ресурс]. URL: https://www.bundeswahlleiter.de/bundestagswahlen/2017/ergebnisse.html (Data obrashhenija: 07.10.2017.)

Koalitionsvertrag zwischen CDU, CSU und SPD. Ein neuer Aufbruch für Europa. Eine neue Dynamik für Deutschland. Ein neuer Zusammenhalt für unser Land 2018 // Sozialdemokratische Partei Deutschlands (SPD): Official Website [Электронный ресурc]. URL: https://www.spd.de/ fileadmin/Dokumente/Koalitionsvertrag/Koalitionsvertrag_2018.pdf (Data obrashhenija: 17.02.2018.)

Langfassung des Wahlprogramms zur Bundestagswahl 2017. Sozal gerecht. Frieden. Für alle. Die Zukunft, für die wir kämpfen! 2017 // DIE LINKE: Official Website [Электронный ресурс]. URL: https://www.die-linke.de/fileadmin/download/wahlen2017/wahlprogramm2017/die_linke_ wahlprogramm_2017.pdf (Data obrashhenija: 25.09.2017.)

Programm für Deutschland. Wahlprogramm der Alternative für Deutschland für die Wahl zum Deutschen Bundestag am 24 September 2017 // Alternative für Deutschland (AfD): Official Website [Электронный ресурс]. URL: https://www.afd.de/wp-content/uploads/sites/111/ 2017/06/2017-0601_AfD-Bundestagswahlprogramm_Onlinefassung.pdf (Data obrashhenija: 25.09.2017.)

Regierungsprogramm CDU / CSU 2017-2021. Für ein Deutschland in dem wir gut und gerne leben 2017 // Christlich Demokratische Union Deutschlands (SDU): Official Website [Электронный pecypc]. URL: https://www.cdu.de/system/tdf/media/dokumente/170703regierungsprogramm2017.pdf (Data obrashhenija: 25.09.2017.)

Unser Regierungsprogramm für Deutschland. Zeit für mehr Gerechtigkeit 2017// Sozialdemokratische Partei Deutschlands (SPD): Official Website [Электронный pecypc]. URL: https:// www.spd.de/fileadmin/Dokumente/Bundesparteitag_2017/Es_ist_Zeit_fuer_mehr_Gerechtigkeit-Unser_ Regierungsprogramm.pdf (Data obrashhenija: 24.09.2017.) 